\title{
GCU
}

Glasgow Caledonian

University

University for the Common Good

\section{Do community empowerment and enabling state policies work in practice? Insights from a community development intervention in rural Scotland}

Markantoni, Marianna; Steiner, Artur; Meador, John Elliot; Farmer, Jane

Published in:

Geoforum

DOI:

10.1016/j.geoforum.2018.10.022

Publication date:

2018

Document Version

Author accepted manuscript

Link to publication in ResearchOnline

Citation for published version (Harvard):

Markantoni, M, Steiner, A, Meador, JE \& Farmer, J 2018, 'Do community empowerment and enabling state policies work in practice? Insights from a community development intervention in rural Scotland', Geoforum, vol. 97, 97 (2018), pp. 142-154. https://doi.org/10.1016/j.geoforum.2018.10.022

\section{General rights}

Copyright and moral rights for the publications made accessible in the public portal are retained by the authors and/or other copyright owners and it is a condition of accessing publications that users recognise and abide by the legal requirements associated with these rights.

Take down policy

If you believe that this document breaches copyright please view our takedown policy at https://edshare.gcu.ac.uk/id/eprint/5179 for details

of how to contact us. 
Markantoni, M., Steiner, A., Meador, E. and Farmer, J. (2018) Do community empowerment and enabling state policies work in practice? Insights from a community development intervention in rural Scotland. Geoforum, 97, 142-154.

\title{
Do community empowerment and enabling state policies work in practice? Insights from a community development intervention in rural Scotland.
}

\begin{abstract}
In the transition from welfare to 'enabling' states, governments move away from their previous roles as providers of services. Individuals and communities as collectives of individuals are encouraged to play a more active role in improving their own wellbeing and resilience, thus shifting from dependence on the state to self-reliance. This proposed transformation is highly complex and poorly understood. We question whether government interventions and policies aimed at strengthening community empowerment can lead to an enabling state. By examining externally funded community projects in six rural Scottish villages, we investigate whether these development initiatives helped to improve socio-economic aspects related to community resilience. We used uni/bivariate and multivariate analysis with data from 345 structured interviews. Our results show that those communities where projects were completed had a higher average social resilience than the communities where projects remained incomplete. Social resilience factors, including social ties and networks, were predictors of completing community projects. Our results indicate that some communities are harder to activate and require external state support which addresses local needs so that these communities play a more active civic role. If states seek 'resilient communities', interventions must be co-designed with citizens to create conditions that will engage and enable people to take more control of aspects of their future, including those communities with a history of minimal civic participation.
\end{abstract}

Keywords: community resilience; community development; LEADER programme; rural communities; enabling state; neoliberalism 
Markantoni, M., Steiner, A., Meador, E. and Farmer, J. (2018) Do community empowerment and enabling state policies work in practice? Insights from a community development intervention in rural Scotland. Geoforum, 97, 142-154.

\section{Introduction}

In the wake of welfare state restructuring, the necessity of mobilising community actors to work collectively to address local challenges has been widely discussed in policy and research literature (Steiner and Farmer, 2017). In the United Kingdom (UK), policies are shifting from paternalistic approaches and are purportedly aiming towards inclusive citizen participation. Examples of communities in Scotland co-producing services have been highlighted/cited in the Christie Commission report (2011) and by researchers (Muñoz et al., 2015). UK governments consider citizen participation in local initiatives and service delivery significant for enhancing 'community resilience' - a concept that implies an adaptive capacity of community members for enhanced regional sustainability (Dawley et al., 2010; Farmer et al., 2008). The withdrawal of public funding from community-led development projects is addressed by alternative funding from, for example, social investment funds, crowd sourcing and philanthropic organisations (Harrow and Jung, 2016). This situation is typical of citizens' experiences in the shift from welfarist to neoliberal modes of government (Cheshire et al., 2015). National governments increasingly expect individuals and communities (defined here as people living in the same geographical location) to bear responsibility for individual and collective wellbeing and development. Given the discussions and negotiations surrounding Brexit, there is now greater uncertainty than ever before in the UK about the future of the current welfare state (Prime Minister's Office, 2017).

Despite this ambiguity, or arguably because of it, the transition from a culture of state reliance towards more active forms of citizenship with minimum state intervention is a current priority in UK policies. This signals significant change in the processes by which society is governed (Elvidge, 2012; 2014). In a context of deregulation and reduced public expenditure, community-led local development has the potential to influence the future trajectories of locales (Westwood, 2011). Bock (2016) argued that a 
Markantoni, M., Steiner, A., Meador, E. and Farmer, J. (2018) Do community empowerment and enabling state policies work in practice? Insights from a community development intervention in rural Scotland. Geoforum, 97, 142-154.

shift of power from governments to communities can conceal the withdrawal of the state from its duties, resulting in ever more vulnerability in communities that are less engaged with civic activity.

In the current policy environment, developing community resilience is critical for maintaining the economic and social vitality of communities (Johansen and Chandler, 2015). There are various policy instruments and interventions targeted at growing this somewhat intangible resource (Wilson, 2012a). However, community resilience remains a problematic concept, partly because it is essentially an invention of policymakers who apply it without defining what it is or what a resilient, or non-resilient, community would look like (Needham, 2008). This is linked to the practical problem of a lack of agreed methods and indicators to delineate community resilience (Steiner and Markantoni, 2014). Transitioning to an 'enabling state' will require a clearer consensus on the definition of resilience and a better understanding of the processes that contribute to developing and maintaining resilience.

This paper investigates whether community development initiatives (such as the EU LEADER Program $^{1}$ ) help to improve social and economic aspects of community resilience. We build on the Mixed-Methods Analytical Resilience Framework and empirical findings of Steiner and Markantoni (2014) and Steiner et al. (2016). Using this method to assess community resilience in this paper, we apply it at the individual and community levels to measure changes in economic and social resilience resulting from the Capacity for Change (C4C) initiative implemented in rural Scotland during 20112013. C4C aimed to build community resilience and capacity to address local challenges in communities where local services (e.g. school, church, post-office, banks and other local shop closures) had been lost.

\footnotetext{
${ }^{1}$ LEADER (i.e. Liaison Entre Actions de Dévelopement de l'Économie Rurale) is a European Union programme supporting local, bottom-up rural community development. For more information, see: http://www.scotland.gov.uk/Topics/farmingrural/Rural/Leaderapproach2014-20 [accessed 28 March 2018].
} 
Markantoni, M., Steiner, A., Meador, E. and Farmer, J. (2018) Do community empowerment and enabling state policies work in practice? Insights from a community development intervention in rural Scotland. Geoforum, 97, 142-154.

\section{Welfare State to Enabling State ${ }^{2}$}

Moving towards an enabling state has been the foundation of many contemporary UK policies about community (see Conservative Party, 2015; Communities and Local Government, 2008). Elvidge (2012) depicted the birth of the enabling state, a term used since the 1980s as a part of the 'liberalisation revolution' (Cable, 1994, p. 24). In the enabling state, there is a shift from state to market provision of goods and services, and the traditional role of the state shrinks as services are corporatized and privatised (Cope et al., 1997). There is a danger, however, that an enabling state could also be perceived as a distant and uncaring state that delegates its responsibilities to other segments of the market and society.

Earles and Moon (2000) argued that it is not viable for governments to have a monopoly on public service provision, and encouraged collaboration with other organisations. Some goods and services may be more amenable to public (or, conversely, private) provision than others, and this should be carefully explored when states redesign public service provision (Gilbert, 2005). Gilbert (2005) warned against development strategies that become overly concerned with economic efficiency and lose sight of social protection.

Shucksmith (2012) noted that an enabling state should not be an 'absent state'. This indicates the need for a new governance approach which directs the focus on 'responsibilising' a greater array of individuals and organisations (Coaffee, 2013). In such an approach, communities and individuals would not be left alone to solve their local challenges, and a more collaborative approach involving different actors

\footnotetext{
${ }^{2}$ There are different levels of administrative scales within the 'state' including national governments, Local Authorities, Councils or Municipalities and other organisations that operate on behalf of the government. We recognise that many national community development policy frameworks have not always been translated into practice on the ground in communities and, frequently, there is mismatch between national policies and their interpretation by local governments/administrative bodies (Steiner and Teasdale, 2017, Farmer at al., 2008). For the purposes of this paper, the term 'state' refers to the level of the high level, national governments where policies are generated.
} 
Markantoni, M., Steiner, A., Meador, E. and Farmer, J. (2018) Do community empowerment and enabling state policies work in practice? Insights from a community development intervention in rural Scotland. Geoforum, 97, 142-154.

(residents, public, private, third sectors) should be considered. This quote from Coaffee et al. $(2008$, p. 3$)$ is illustrative:

Resilience cannot simply be left to communities themselves but requires steering, not rowing, from state level in some form of collaborative alliance to be successful. Arguably, the building of such resilience will be most effective when it involve[s] a mutual and accountable network of civic institutions, agencies and individual citizens working in partnership towards common goals within a common strategy.

Discussing community sustainability, Elliot (2014, p. 26) distinguished between empowered and disempowered communities, where empowered communities comprise individuals that are confident, energetic and independent, and disempowered communities are characterised by dependence on external resources. Considering Elliot's (2014) comments, can the enabling state be a genuinely empowering state for citizens and communities? Cope et al. (1997) argued that the state must be 'able to enable' and to create opportunities for participation locally for collectives, families and individuals. Elvidge (2014, p. 11) pointed out that sometimes governments can lead communities on, and then abandon them when they may need ongoing or varying support: 'the state can provide a powerful helping hand, [but] often a hand that lets go rather than one which holds on'. Governments can help to create conditions to mobilise and support individuals and community groups, but the latter require firm initiatives of government support. Governments should be open and adaptive in their support for communities with varying states of self-sufficiency and leadership, and with different human resources. Elvidge (2014, p. 4) presented four propositions to justify or legitimise the idea of the enabling state:

1) The state is excellent at providing standardised services, but its ability to improve wellbeing in all circumstances is limited; 
Markantoni, M., Steiner, A., Meador, E. and Farmer, J. (2018) Do community empowerment and enabling state policies work in practice? Insights from a community development intervention in rural Scotland. Geoforum, 97, 142-154.

2) Certain areas of wellbeing can be best improved through interactions with friends and family and through community activity;

3) To improve wellbeing a fundamental rethinking of the state's relationship to citizens and communities is required;

4) The state should continue providing the public services that it excels at. It should assume a new role - that of the 'Enabling State' - empowering and supporting communities, individuals and families to be more active in improving their own wellbeing.

While considerable holes can be picked in these statements, they are indicative of a current policy ideology - suggesting that much is expected from citizens and communities in contributing to local wellbeing and risk management. Here, using data from a Scottish rural study, we critique the extent to which Elvidge's (2014) propositions play out in practice.

In Scotland, devolution of power to the local level, reconfiguration of public services, community engagement and community empowerment are facets within a policy umbrella aiming at social action and active citizenship. When the Scottish Parliament was formed in 1999, one goal was to move from a top-down model of government towards inclusive local governance (Brown, 2001). The 'Scottish model' was characterised by a collectivist approach to public service provision. This included the creation of COSLA - the Convention of Scottish Local Authorities - which focuses on local priorities and the implementation of 'Single Outcome Agreements', and supports the development of Community Planning Partnerships (i.e. local partnerships between public services and communities aimed at informing local development plans) (The Commission on Strengthening Local Democracy, 2014).

Scotland has implemented participatory budgeting, in which local people have a direct say in some public funds distribution (Scottish Government, 2015a). Scotland 
Markantoni, M., Steiner, A., Meador, E. and Farmer, J. (2018) Do community empowerment and enabling state policies work in practice? Insights from a community development intervention in rural Scotland. Geoforum, 97, 142-154.

takes an asset-based approach to community development and public services, focusing on application of the resources of individuals and communities. The role of government is then, supposedly, to assist people and communities to achieve useful change using local knowledge, skills and resources (Scottish Government, 2013). The Scottish policy landscape aims to create opportunities for strengthening local democracy and shifting the focus to community action drawing on local assets. The current Scottish Government has expressed willingness to work with communities through service co-design and service co-production (Scottish Government, 2015c), and its aspiration is 'to be the most accessible Government Scotland has ever had' (Scottish Government, 2015a, p. 74). The Government's ambitions to empower communities are reiterated in policy (Skerratt et al., 2016). For example, the Community Empowerment Act (Scottish Government, 2015b) creates opportunities for community groups to contribute to the development of local services and management of assets, and to inform public bodies about local needs and how these could be addressed.

Despite policy developments, Skerratt and Steiner (2013) argue that it is the 'most experienced communities' that come forward and become increasingly empowered, while others fall further behind. By 'most experienced communities' they mean localities with community groups and leaders able to influence local decisions, implement new community development projects, and address local challenges. They also recognise the fluidity of in-community interests and powers, and refer to differences between individual and community-level aspirations. This reinforces Shortall's criticism of 'a romantic, naive view of rural communities, where civic harmony and inclusion triumphs and where there is little room for power struggles, exclusionary tactics by privileged groups, or ideological conflicts' (2004, p.110). In reality, communities are not always coherent but full of power asymmetries. 
Markantoni, M., Steiner, A., Meador, E. and Farmer, J. (2018) Do community empowerment and enabling state policies work in practice? Insights from a community development intervention in rural Scotland. Geoforum, 97, 142-154.

As participation in active decision making is not every citizen's desire, it is necessary to understand that some citizens will be more involved than others, but that even those who do not participate will - over time - be affected by the general trend of progressively active involvement in civic action. And even getting any citizens engaged will require 'start-up', and potentially ongoing, support for citizens' empowerment and engagement (Brodie, 2015).

A significant macro-scale question is whether Scotland can move towards an enabling type of government without further exacerbating the inequalities of community-level capacity and empowerment. For equivalent development, levels of empowerment really must be consistent across communities (Carnegie UK Trust, 2013). However, community participation and empowerment cannot always be ensured. There are communities where citizens are collectively much less active in civic engagement, and where there is little interest in participating in service coproduction or community development activities.

Following on from the above discussion, policy documents often neglect to consider the reality that the level of readiness of citizens to engage varies between communities. Policy also implies that community resilience is a given regardless of the community's social, economic, environmental, cultural and historical context and thus its state of current human resources. Steiner (2016) noted that UK policies face significant challenges in addressing the issue of what policymakers term 'hard to reach'3 communities, where local people are less interested in engagement and participation in government-led community resilience-oriented development. Due to this mismatch between ideology, policy and reality, some communities are less able to draw on resources from the state (Woods, 2016). Steiner and Farmer (2017) noted that the successful implementation of community empowerment policies requires appropriate

\footnotetext{
${ }^{3}$ Note: the term 'hard to reach' relates to communities with no history of engagement as collectives.
} 
Markantoni, M., Steiner, A., Meador, E. and Farmer, J. (2018) Do community empowerment and enabling state policies work in practice? Insights from a community development intervention in rural Scotland. Geoforum, 97, 142-154.

support structures and processes to transfer power from state to people in communities. They stress that policies alone are insufficient to enable empowerment to happen. Some communities do not want to participate in community development programmes due to lack of pre-preparedness (which might be termed 'community capacity'), and even with external support, what policy terms 'empowerment processes', they face many challenges and may fail.

Academics (e.g. Shortall, 2008; Meador and Skerratt, 2017; Navarro et al., 2015) highlight the need to examine community engagement to understand whether it includes those who are less networked, resourced or affluent. Shucksmith (2000, p. 215) explained that marginalised communities are less likely to participate in local development processes 'unless explicit attention is given to their inclusion' and that communities with well-established partnerships and networks are more successful at obtaining funding. In a later paper, Shucksmith (2012) argued that, although state public service provision was weakening, more affluent communities with greater institutional capacity were able to defend their interests and pursue their objectives by taking advantage of the various government schemes.

Studies have shown that responses to engagement in shaping the future of communities are varied. Individual, and collective community, choices around embracing participation (or not) are legitimate. In some instances, decisions not to participate may be a sign of confidence rather than apathy (Skerratt and Steiner, 2013; Dare et al., 2014). Still, participation of local citizens in community affairs is promoted as an essential component of community empowerment and building community resilience (Grove, 2014). This participation is said to underpin adaptation to changing circumstances, and is therefore necessary if communities are to pursue and achieve goals (Tohidi and Jabbari, 2012). Community development programmes that support community participation and empowerment, therefore, might be crucial in providing 
Markantoni, M., Steiner, A., Meador, E. and Farmer, J. (2018) Do community empowerment and enabling state policies work in practice? Insights from a community development intervention in rural Scotland. Geoforum, 97, 142-154.

local people with the capacity to respond to change, achieve positive outcomes and develop resilience (Mohan and Stokke, 2000).

\section{Resilience as an analytical framework}

Community resilience as a concept has rapidly gained currency in policy and academic parlance, understood as a process and outcome of development and a movement towards more sustainable community development (Adger, 2000, 2006; Mitchell, 2013; Scott, 2013; Wilson, 2013, 2015; Wright, 2016). This popularity has grown because resilience is a summary of the evolutionary dynamics enabling systems and communities to respond and adapt to change (Darnhofer et al., 2016; Imperiale and Vanclay, 2016). Despite growing interest in community resilience, the concept is still illdefined and fuzzy at the theoretical level (Davoudi, 2012; Herman, 2016; McEvoy et al., 2013; Mitchell, 2013).

We understand community resilience as a social process experienced at the community level, which involves taking action to address social, economic and environmental challenges. However, this approach has conceptual limitations. The concept is too vague to inform a concrete methodology to assess resilience, which would then help communities to develop and sustain resilience (Mitchell, 2013). The social processes of resilience are little understood. For this reason, Imperiale and Vanclay (2016) call for a greater effort to understand, recognise and strengthen the capacities of the resilient social processes that communities enact in order to overcome the challenges experienced in crises.

Previous studies have identified resilience as a multi-scalar concept with interrelated thematic aspects of social and economic resilience operating at both individual and collective (community) levels (Steiner and Markantoni, 2014). Wilson (2012b, p. 123) argued that community resilience is best conceptualised as 'how well the critical 
Markantoni, M., Steiner, A., Meador, E. and Farmer, J. (2018) Do community empowerment and enabling state policies work in practice? Insights from a community development intervention in rural Scotland. Geoforum, 97, 142-154.

triangle of economic, social and environmental capital is developed in a given community and how these capitals interact'. Similarly, McManus et al. (2012) concluded that community resilience is not about social versus economic, but involves a viable local economy, the quality of the local environment and a strong sense of place among local residents. In the same vein, Kelly et al. (2015) and Wilson et al. (2018) argued that what makes communities resilient is how well developed the economic, institutional, social, cultural and natural domains are, highlighting that these five domains are closely interlinked and therefore 'weakening factors within one domain can also weaken factors in other domains' (Kelly et al. 2015, p. 12).

Although we recognise the debates around the type and nature of 'capitals' (see Vanclay et al., 2015; Smyth and Vanclay, 2017; Wilson, 2013), here we focus on the social and economic dimensions at the individual and community levels. These two critical dimensions are applied in this paper as an initial means to explore a gateway to mapping out community resilience.

The social dimension is regarded as a key component of resilient communities and is a proxy for understanding social relationships (Magis, 2010). Social dimensions include community member interactions, trust, engagement, conflict resolution processes, strength of networks, bonding and bridging capitals, as well as community 'cohesiveness' (Rigg et al., 2012). For example, the community engagement of community members working together in challenging times plays an important role in strengthening community-level resilience (Schwarz et al., 2011). The feeling of being part of a community and having community spirit can help to build networks that incorporate less-resilient individuals and groups (Hegney et al., 2007). According to Zwiers et al. (2018), community action can have both change-oriented components and stability-oriented components that help to foster community resilience. While the emotional bonds between people and place are complex (Lewicka, 2011), they are significant in people's attitudes and behaviours towards a sustainable future for people 
Markantoni, M., Steiner, A., Meador, E. and Farmer, J. (2018) Do community empowerment and enabling state policies work in practice? Insights from a community development intervention in rural Scotland. Geoforum, 97, 142-154.

and their locale (Zwiers et al., 2018). Furthermore, communities with weak social bonds can be a sign of vulnerability, and as a result community interests may become fragmented (Wilson et al., 2016).

The economic dimension, although criticised for being over-emphasised in contemporary resilience assessments, is an integral part of local financial and social sustainability. The local economies of resilient communities require diverse businesses, employment opportunities and various local services (Steiner and Atterton, 2015). Economic growth or decline influences social life and lifestyles and, therefore, the social and economic dimensions are interlinked (Wilkinson, 1991).

In this paper we build on the Mixed-Methods Analytical Framework for measuring community resilience and change over time, and empirical findings presented by Steiner and Markantoni (2014) and Steiner et al. (2016). As the C4C programme focused on building the capacity to develop socio-economic resilience, we collected data covering these two dimensions. In this paper we concentrate on the social and economic dimensions of resilience and explore four outcomes: (i) individual social resilience, (ii) community social resilience, (iii) individual economic resilience, and (iv) community economic resilience (REFERENCE REMOVED FOR BLIND REVIEW) (see Figure 1).

Figure 1. Key components of community resilience

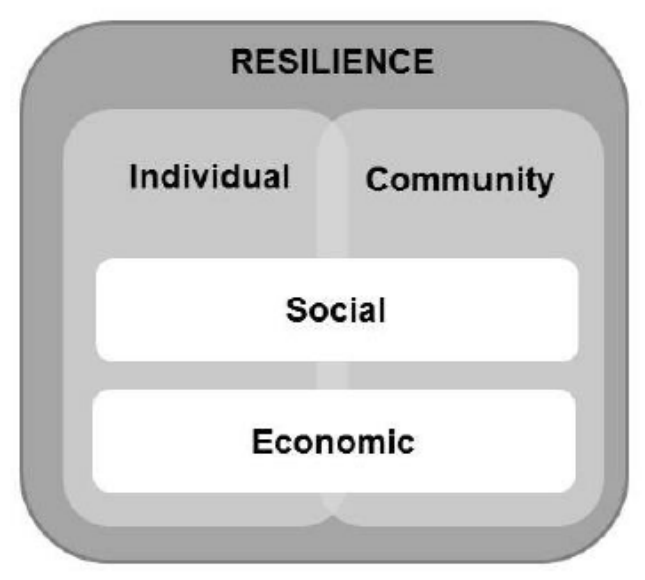


Markantoni, M., Steiner, A., Meador, E. and Farmer, J. (2018) Do community empowerment and enabling state policies work in practice? Insights from a community development intervention in rural Scotland. Geoforum, 97, 142-154.

We argue that measurement of the dimensions in the diagram shows how people that form communities can do things for themselves, be proactive, create opportunities, utilise the skills of community members to increase local employment and income opportunities, and strengthen social networks. This analysis assists in understanding the extent to which there can be a transition from 'dependence' towards self-reliance, as contemporary policy would describe it.

\section{Study background and methodology}

\subsection{The Capacity for Change LEADER-funded project}

C4C was a community development initiative implemented by the regional LEADER office in Dumfries and Galloway in Scotland (hereafter, LEADER implies this specific office). C4C was introduced after observations by LEADER staff who indicated that while some community groups from specific geographical locations had applied for LEADER funding on a regular basis, enhancing their local development, others had never applied. To address the potentially widening disparity between the 'strong and capable' and 'weak and less capable' communities that could emerge from these processes over time, the two-year capacity building C4C project was developed. C4C involved LEADER staff working with communities that met three selection criteria: (i) they had not already received LEADER grants or other major funding supporting community development; (ii) the locations had to have lost some or the majority of local services over recent years and be perceived locally as 'disadvantaged'; and (iii) they must be rural with a small population (< 500 inhabitants). In addition to the delivery of specific projects (i.e. development of local assets or services), C4C aimed to test if and 
Markantoni, M., Steiner, A., Meador, E. and Farmer, J. (2018) Do community empowerment and enabling state policies work in practice? Insights from a community development intervention in rural Scotland. Geoforum, 97, 142-154.

how communities could be mobilised to develop local initiatives and 'community resilience'. The overarching objective of $\mathrm{C} 4 \mathrm{C}$ was to develop capacity for developing local resources and services, enhance inclusion in obtaining grant funding, and enhance resilience measured at the individual and community levels, thereby empowering the participating communities.

C4C was a response to the criticisms of LEADER and other funding programmes that only strong and privileged communities were able to get funding since they had greater capacity and were able to make more effective grant applications (Navarro et al., 2015). A LEADER study from Dax et al. (2013) in Austria and Ireland highlighted the need to concentrate on the local and regional assets of every community in order to have a significant area-specific impact. In particular, the bottom-up approach and local actions are being challenged and many authors are calling for a more comprehensive assessment of impacts (Granberg et al., 2015; Navarro et al., 2015).

C4C was different from other LEADER projects, in that (i) communities did not have to apply for LEADER funding, but rather direct support was offered to the selected communities; (ii) communities did not require matching-funding (i.e. projects were fully funded); and (iii) all projects received mentoring support from an experienced LEADER community development officer. The programme thus addressed some of the challenges associated with current UK and Scottish community resilience policies, testing whether the current policy expectations of, and the transfer of responsibilities to, communities are realistic.

The C4C project focused on six villages in Dumfries and Galloway, a rural region ${ }^{4}$ in the south-west of Scotland (Figure 2). The region is characterised by regional decline, and an ageing and dispersed population. According to the Scottish Index of Multiple Deprivation (Scottish Government, 2017), one of the communities is among the $20 \%$ to

\footnotetext{
${ }^{4}$ According to the Scottish Government 6-fold Urban/Rural classification: approximately $22 \%$ of the D\&G population lives in remote rural areas; $25 \%$ in accessible rural areas; $8 \%$ in small towns; $17 \%$ in accessible small towns; and $28 \%$ in other urban areas. There are no large urban areas in the region.
} 
Markantoni, M., Steiner, A., Meador, E. and Farmer, J. (2018) Do community empowerment and enabling state policies work in practice? Insights from a community development intervention in rural Scotland. Geoforum, 97, 142-154.

$40 \%$ most deprived areas in Scotland, and the remaining communities belong to $40 \%$ $60 \%$ of the most deprived areas.

\section{Figure 2. Dumfries and Galloway study area in Scotland}

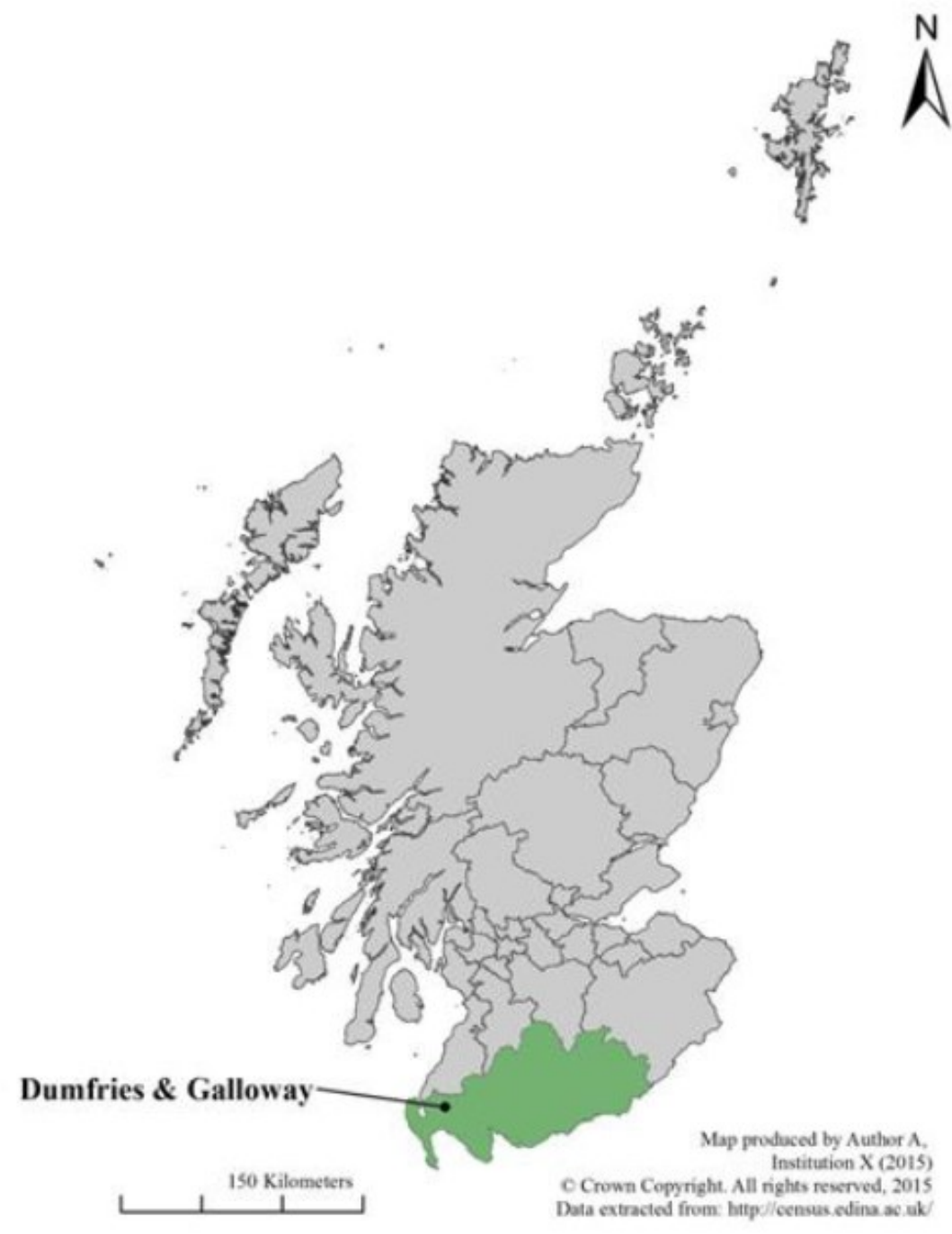

\subsection{Methodology}

We used the analytical framework for measuring community resilience presented by Steiner and Markantoni (2014) and Steiner et al. (2016) to assess the impact of the C4C intervention on social and economic capitals. As such, the C4C study comprised a time series panel design, and a mixed-methods research approach in which selected community members were interviewed at the different rounds of the intervention. 
Markantoni, M., Steiner, A., Meador, E. and Farmer, J. (2018) Do community empowerment and enabling state policies work in practice? Insights from a community development intervention in rural Scotland. Geoforum, 97, 142-154.

In round 1 , the first component of the panel study, we collected quantitative and qualitative baseline data before the $\mathrm{C} 4 \mathrm{C}$ community intervention took place and before study participants had any knowledge of it.

To identify and access interviewees, a snowball sampling approach was used (Bryman and Bell, 2007). Contact details of an initial small number of community members were provided by the LEADER team. In each community, we ultimately collected the views of approximately $10 \%$ of local people (the population of each community was $<500)$. Respondents consisted of community members with diverse socio-demographic characteristics. Table 1 presents the questions the respondents answered by indicating their views on a scale from 0 (very negative) to 10 (very positive). Respondents were also asked some open-ended questions to help explain their quantitative responses. In the findings section, two of these questions (Q24 and Q28) are further discussed to give an in-depth interpretation of the quantitative answers given by the respondents (see Tables 3 and 4). 
Markantoni, M., Steiner, A., Meador, E. and Farmer, J. (2018) Do community empowerment and enabling state policies work in practice? Insights from a community development intervention in rural Scotland. Geoforum, 97, 142-154.

Table 1. C4C Survey questions

\begin{tabular}{|c|c|}
\hline SOCIAL INDIVIDUAL RESILIENCE & ECONOMIC INDIVIDUAL RESILIENCE \\
\hline $\begin{array}{l}\text { Q13 To what extent do you engage with other } \\
\text { members of your community? } \\
\text { Give an example: }\end{array}$ & $\begin{array}{l}\text { Q18 To what extent do you use your skills, } \\
\text { expertise and knowledge you have (in your } \\
\text { village)? } \\
\text { What would encourage you to use your skills } \\
\text { more widely? }\end{array}$ \\
\hline $\begin{array}{l}\text { Q14 To what extent do you use facilities in } \\
\text { your village (e.g. village hall, shop, business, } \\
\text { post office, community spaces, bus stop, } \\
\text { school)? }\end{array}$ & $\begin{array}{l}\text { Q19 To what extent do you think you would be } \\
\text { able to develop your skills in your village? }\end{array}$ \\
\hline $\begin{array}{l}\text { Q15 How much do you use green spaces (e.g. } \\
\text { community gardens, playgrounds) and } \\
\text { appreciate the natural environment (e.g. with } \\
\text { views of trees or open space) in your } \\
\text { community? }\end{array}$ & $\begin{array}{l}\text { Q20 To what extent are local natural (i.e. } \\
\text { landscape, materials that produce goods and } \\
\text { services; renewable energy), cultural (i.e. } \\
\text { library resources, history, heritage) and built } \\
\text { (i.e. fixed assets which facilitate the livelihood } \\
\text { and well-being of the community) resources } \\
\text { accessible to you to improve your economic } \\
\text { situation? }\end{array}$ \\
\hline $\begin{array}{l}\text { Q16 To what extent are you happy with your } \\
\text { life in this community? } \\
\text { Why? }\end{array}$ & $\begin{array}{l}\text { Q21 How would you rate your personal } \\
\text { financial stability/security? }\end{array}$ \\
\hline $\begin{array}{l}\text { Q17 To what extent do you feel part of this } \\
\text { community? } \\
\text { What makes you feel that? }\end{array}$ & $\begin{array}{l}\text { Q22 To what extent do services and } \\
\text { infrastructure in your village meet your current } \\
\text { and likely future needs? }\end{array}$ \\
\hline ECONOMIC COMMUNITY RESILIENCE & SOCIAL COMMUNITY RESILIENCE \\
\hline $\begin{array}{l}\text { Q23 To what extent do available services (e.g. } \\
\text { village halls, shops, a post office) meet existing } \\
\text { and future business needs of the village? }\end{array}$ & $\begin{array}{l}\text { Q28 To what extent are all members in the } \\
\text { community encouraged to be involved in } \\
\text { community life? } \\
\text { Give examples: }\end{array}$ \\
\hline $\begin{array}{l}\text { Q24 To what extent do community groups } \\
\text { work together to generate income for the } \\
\text { village? } \\
\text { Give examples: }\end{array}$ & $\begin{array}{l}\text { Q29 To what extent do your community } \\
\text { members utilise, maintain and care for existing } \\
\text { natural, cultural, built and human resources in } \\
\text { the village? }\end{array}$ \\
\hline $\begin{array}{l}\text { Q25 To what extent does your community use } \\
\text { village-based goods and services? }\end{array}$ & $\begin{array}{l}\text { Q30 To what extent do you think your } \\
\text { community succeeds in developing and } \\
\text { improving this village? } \\
\text { Give examples. How this could be improved? }\end{array}$ \\
\hline $\begin{array}{l}\text { Q26 To what extent do you think your } \\
\text { community makes most of what it has to } \\
\text { improve its economic situation? } \\
\text { How this could be improved? }\end{array}$ & $\begin{array}{l}\text { Q31 To what extent is the community you live } \\
\text { in able to learn from the past in order to } \\
\text { develop ideas for the future? }\end{array}$ \\
\hline $\begin{array}{l}\text { Q27 To what extent do you think this village is } \\
\text { capable of developing more job opportunities? } \\
\text { How this would happen? }\end{array}$ & $\begin{array}{l}\text { Q32 How strong is the sense of community } \\
\text { determination to act together in the village? } \\
\text { Why do you think that? }\end{array}$ \\
\hline
\end{tabular}

* $\quad$ All questions were measured using a Linkert Scale 1-10. 
Markantoni, M., Steiner, A., Meador, E. and Farmer, J. (2018) Do community empowerment and enabling state policies work in practice? Insights from a community development intervention in rural Scotland. Geoforum, 97, 142-154.

Round 2 was conducted after completion of C4C (i.e. 18-24 months after the C4C initiation) and involved conducting interviews with as many of the round 1 interviewees as possible and repeating the round 1 interview questions. This longitudinal approach enabled the calculation of change based on self-reported measures of the level of community capitals (Wilson, 2012b).

The questionnaire used in rounds 1 and 2 included questions focused specifically on topics of resilience relating to Wilson's (2012a) theory of community resilience, which centres on economic and social themes. Survey questions were designed to measure each type of resilience relating to Wilson's model. The resilience scale covers four key domains: Social Individual Resilience (SIR); Social Community Resilience (SCR); Economic Individual Resilience (EIR); and Economic Community Resilience (ECR).

SIR is measured by indicators related to how local residents engage with other community members, whether they are happy and feel part of their community, whether they utilise their community green spaces and whether they use facilities located in their community (i.e. Q13-17). SCR indicators consider the extent to which community members engage in community life, utilise community, natural, cultural, built and human resources, learn from past experiences, develop new ideas and improve their village, and whether their determination to act together is strong (i.e. Q28-32). EIR is measured by indicators relating to the extent to which local residents use their skills and knowledge in their community, are able to further develop their skills, access local resources to improve their individual economic situation, how they rate their individual financial situation, as well as the extent to which the services and infrastructure in the community meet their personal needs (i.e. Q18-22). ECR indicators measure whether local services meet existing and future community needs, whether different community groups work together to generate income for the community, whether the community uses village-based services, whether the community improves its economic situation and creates job opportunities (i.e. Q23-27). 
Markantoni, M., Steiner, A., Meador, E. and Farmer, J. (2018) Do community empowerment and enabling state policies work in practice? Insights from a community development intervention in rural Scotland. Geoforum, 97, 142-154.

Over the two rounds of the study, a total of 345 face-to-face interviews were conducted with community members from six C4C communities. For confidentiality reasons and to ensure interviewees' anonymity, the geographical locations of the C4C communities are not disclosed. Interviews lasted 40-120 minutes (consent was received from all approached). The data were then transcribed, coded and analysed using NVivo for qualitative, and SPSS for quantitative, data analysis ${ }^{5}$.

The research was conducted consistent with social research ethics (Vanclay et al., 2013) and institutional research ethics approval was given by INSTITUTION NAME WITHHELD FOR BLIND REVIEW.

\section{Analysis}

Of the six communities studied, three completed and finalised their projects ${ }^{6}$ within the two-year time-frame; these are labelled C1, C2, C3 (i.e. Completed 1, 2, 3). Three communities did not complete and finalise within the time frame; these uncompleted projects are labelled U4, U5, U6 (i.e. Uncompleted 4, 5, 6). The two groups 'completed projects' and 'uncompleted projects' - were used to 'artificially' cluster the $\mathrm{C} 4 \mathrm{C}$ communities. After community meetings and many discussions about potential projects, there were two communities that failed to even start their projects due to internal disputes. The third community started the implementation of the project but lack of community determination led to the project not being finalised.

Data analysis was conducted using both uni/bivariate and multivariate analysis. First, chi-square tests were performed for key demographic variables of interest with

\footnotetext{
${ }^{5}$ Note: this paper focuses on presenting quantitative findings; qualitative findings are used sporadically to support and add to quantitative evidence. Full description of $\mathrm{C} 4 \mathrm{C}$ qualitative findings can be found in Paper 1, Paper 2, Paper 3 (NAMES WITHHELD FOR BLIND REVIEW).

${ }^{6} \mathrm{C} 4 \mathrm{C}$ projects included the development of a new community garden with a seaside viewpoint, a sculpture celebrating the uniqueness of a village, a new kitchen facility in a village hall, a path linking two villages and enhancement of a heritage trail.
} 
Markantoni, M., Steiner, A., Meador, E. and Farmer, J. (2018) Do community empowerment and enabling state policies work in practice? Insights from a community development intervention in rural Scotland. Geoforum, 97, 142-154.

programme outcome. Then an Analysis of Variance model (ANOVA) was performed.

The following sections review both approaches as well as the results of each approach.

\subsection{Bivariate analysis}

Figure 3 shows a demographic overview of completed and uncompleted projects between rounds. Gender, educational qualification and age are plotted. Overall, there were more female participants (about $20 \%$ more females than males). Similarly, about $60 \%$ of respondents of both the completed and uncompleted projects had no higher education qualifications. An exception to this was the second round for the uncompleted projects, where the number of participants with no qualifications dropped from 33 to 28 while the number of participants with qualifications rose from 23 to 28 . This left the uncompleted projects at round 2 with a $50 \%-50 \%$ split between levels of qualification. Age was originally recorded in a numeric format where respondents were asked to indicate their age. This variable was then recoded into equal bins. The majority of respondents were close to pension age, with about a third of respondents over 66 years of age. There is no linear trend between completed and uncompleted projects in respondent age, other than project participants in general being older. 
Markantoni, M., Steiner, A., Meador, E. and Farmer, J. (2018) Do community empowerment and enabling state policies work in practice? Insights from a community development intervention in rural Scotland. Geoforum, 97, 142-154.

Figure 3. Demographic overview of project participants in completed and uncompleted $\mathrm{C} 4 \mathrm{C}$ projects
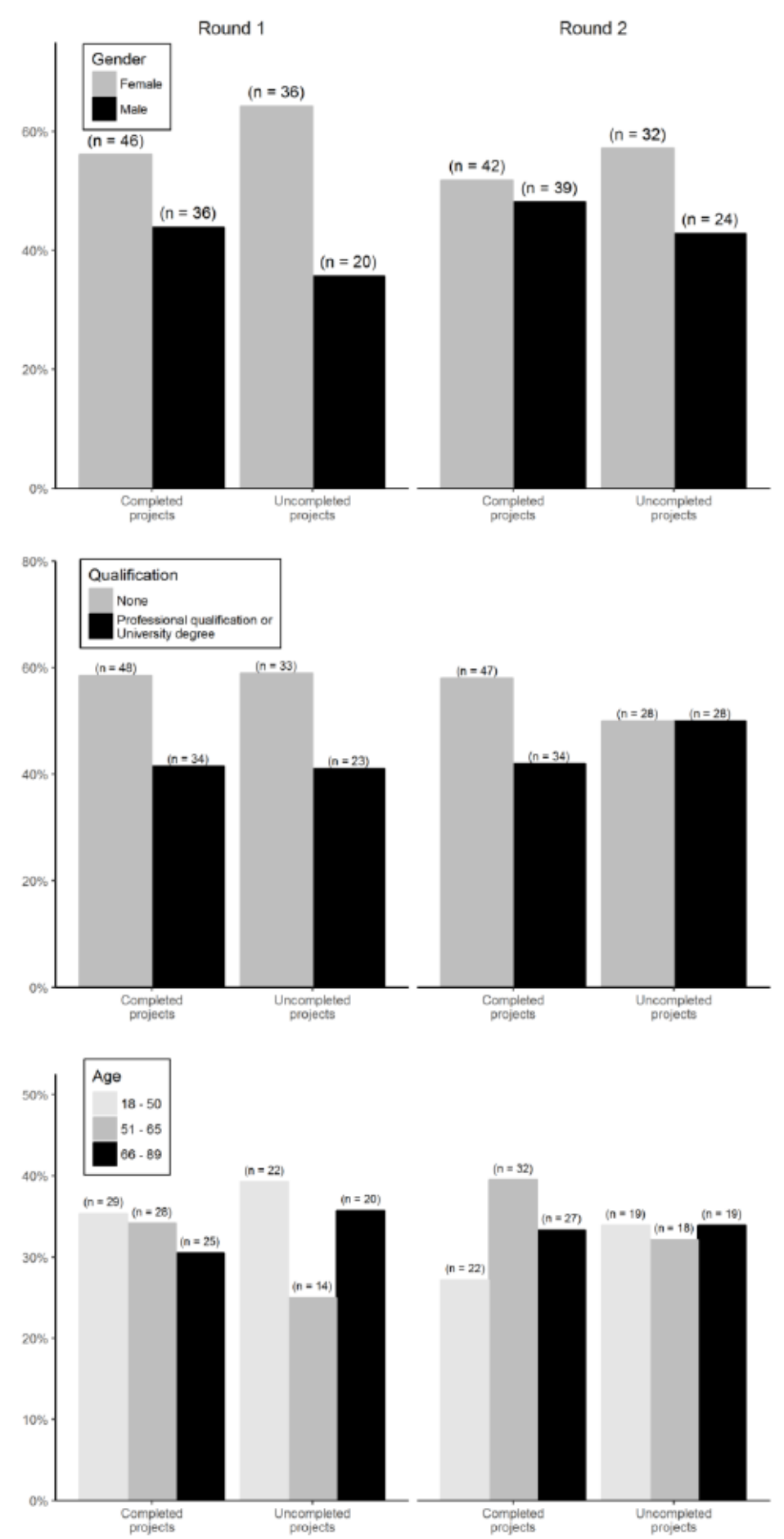

The change in average resilience scores between rounds and programme outcome is presented in Figures 4 and 5. Figure 4 compares average types of resilience between 
Markantoni, M., Steiner, A., Meador, E. and Farmer, J. (2018) Do community empowerment and enabling state policies work in practice? Insights from a community development intervention in rural Scotland. Geoforum, 97, 142-154.

completed and uncompleted projects, while Figure 5 shows the same statistic between rounds.

As shown in Figure 4, community groups that finished their projects within the given timeline showed higher levels of resilience in ECR and SCR, the biggest difference being in SCR. Overall, all communities (with both completed and uncompleted community projects) had low economic resilience and high social resilience when averaged between rounds, though communities that completed their projects had a higher (close to 10\%) social community resilience score than communities that did not complete their projects.

Figure 5 expands on Figure 4 by separately illustrating the difference between rounds for communities with completed and uncompleted projects. Communities that completed their C4C projects showed a statistically significant increase in ECR, EIR and SIR, and an increase (though not statistically significant) in SCR. Conversely, a statistically significant difference between rounds was noted for communities that failed to complete projects for all resilience levels except of EIR (where the decrease was not statistically significant). 
Markantoni, M., Steiner, A., Meador, E. and Farmer, J. (2018) Do community empowerment and enabling state policies work in practice? Insights from a community development intervention in rural Scotland. Geoforum, 97, 142-154.

Figure 4. Comparison of resilience types by outcome Grouped by outcome

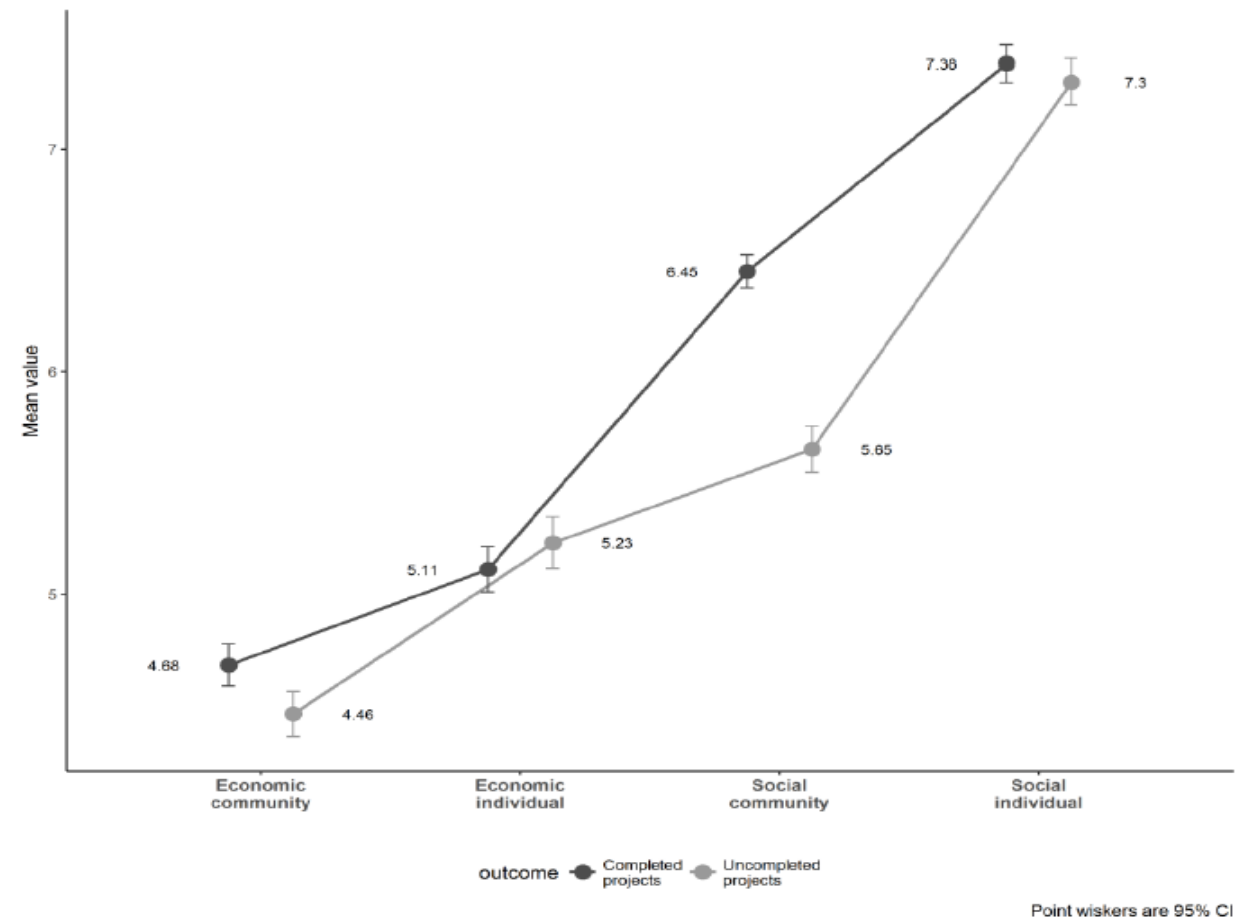

Figure 5. Comparison of resilience type by outcome and round Faceted by outcome

Grouped by round

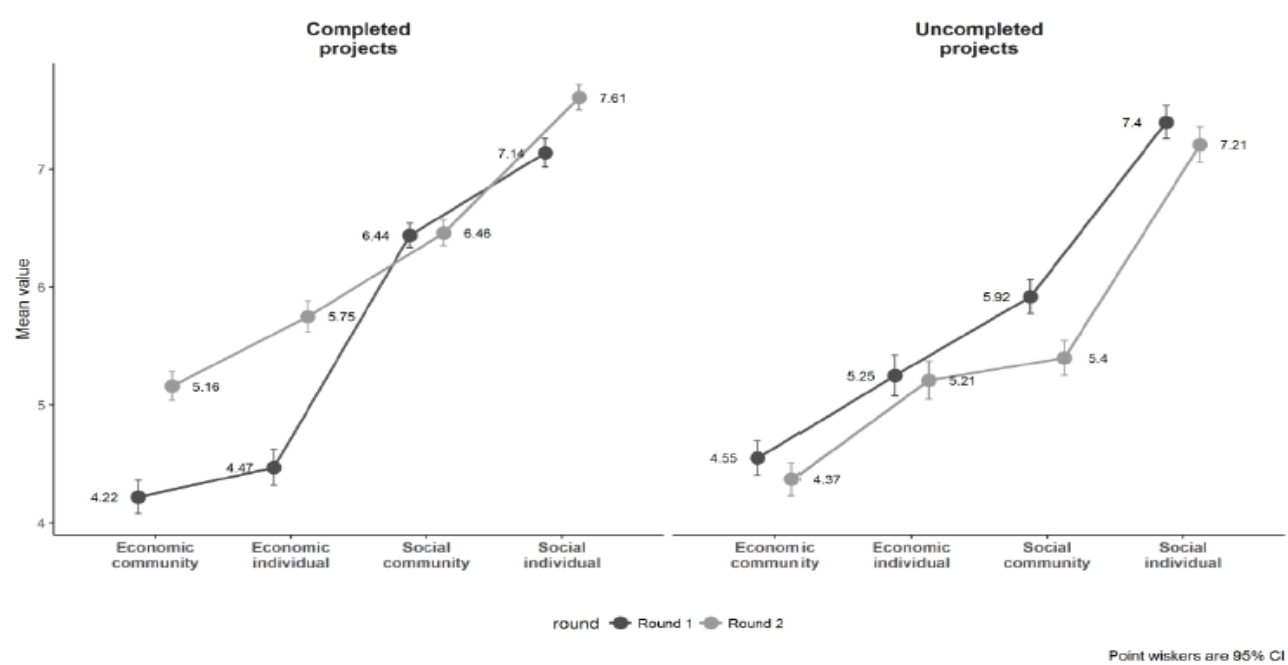


Markantoni, M., Steiner, A., Meador, E. and Farmer, J. (2018) Do community empowerment and enabling state policies work in practice? Insights from a community development intervention in rural Scotland. Geoforum, 97, 142-154.

\subsection{Linear Model}

The t-test results show the differences between the $\mathrm{C} 4 \mathrm{C}$ rounds for each resilience indicator. These results are supplemented by two general linear models that account for the change between the two rounds of data collection and between community resilience indicators. Table 2 shows the ANOVA results, which compare the difference between resilience indicators for communities that completed and those that did not complete their projects. This modelling approach is used as the data characteristics satisfy the model assumptions (Kleinbaum et al., 2013). The factors are the same for both models and represent the mean change between rounds.

Table 2. ANOVA model

\begin{tabular}{|c|c|c|c|c|}
\hline & $\begin{array}{r}\text { Com } \\
\text { pro }\end{array}$ & $\begin{array}{l}\text { leted } \\
\text { ects }\end{array}$ & $\begin{array}{r}\text { Uncomp } \\
\text { proje }\end{array}$ & $\begin{array}{l}\text { pleted } \\
\text { cts }\end{array}$ \\
\hline \multirow{2}{*}{ Economic individual - Economic community } & \multicolumn{2}{|c|}{0.313} & \multicolumn{2}{|c|}{0.179} \\
\hline & -0.549 & 1.175 & -0.623 & 0.980 \\
\hline \multirow{2}{*}{ Social community - Economic community } & \multicolumn{2}{|c|}{$-1.069^{\star \star *}$} & \multicolumn{2}{|c|}{-0.280} \\
\hline & -1.931 & -0.207 & -1.081 & 0.522 \\
\hline \multirow{2}{*}{ Social individual - Economic community } & \multicolumn{2}{|c|}{-0.665} & \multicolumn{2}{|c|}{-0.022} \\
\hline & -1.527 & 0.197 & -0.824 & 0.779 \\
\hline \multirow{2}{*}{ Social community - Economic individual } & \multicolumn{2}{|c|}{$-1.382^{\star \star *}$} & \multicolumn{2}{|c|}{-0.459} \\
\hline & -2.245 & -0.520 & -1.260 & 0.343 \\
\hline \multirow{2}{*}{ Social individual - Economic individual } & \multicolumn{2}{|c|}{$-0.978^{*}$} & \multicolumn{2}{|c|}{-0.201} \\
\hline & -1.840 & -0.116 & -1.003 & 0.601 \\
\hline \multirow{2}{*}{ Social individual - Social community } & \multicolumn{2}{|c|}{0.404} & \multicolumn{2}{|c|}{0.258} \\
\hline & -0.458 & 1.266 & -0.544 & 1.059 \\
\hline$R$ - square & \multicolumn{2}{|c|}{0.2843} & \multicolumn{2}{|c|}{0.04004} \\
\hline Adj. R - square & \multicolumn{2}{|c|}{0.246} & \multicolumn{2}{|c|}{-0.01139} \\
\hline Degree of freedom & \multicolumn{2}{|c|}{56} & \multicolumn{2}{|c|}{56} \\
\hline F distribution & \multicolumn{2}{|c|}{7.415} & \multicolumn{2}{|c|}{0.7786} \\
\hline
\end{tabular}

Table 2 presents two statistical models, each having the same independent variables.

Each model tests the change in resilience scores between rounds. Change between 
Markantoni, M., Steiner, A., Meador, E. and Farmer, J. (2018) Do community empowerment and enabling state policies work in practice? Insights from a community development intervention in rural Scotland. Geoforum, 97, 142-154.

rounds is calculated by taking the average score for each resilience type in round two and subtracting the resilience score in round one. Then each resilience distribution is tested as a parameter in the model. The resulting distributions are approximately normal, and kernel density plots are provided in Appendix 1.

\section{Findings}

Interviewees from communities where C4C projects were completed rated themselves highly for both SCR and SIR across all types of indicators. This provides evidence to suggest that social resilience factors, when compared to economic resilience, are important characteristics of successful community development efforts in formerly unengaged communities. On the other hand, communities with uncompleted projects did not have a statistically significant increase or decrease in neither social nor economic resilience indicators between rounds.

\subsection{Completed and incomplete community projects}

For communities where participants completed their $\mathrm{C} 4 \mathrm{C}$ projects within the given timeline, there were no statistically significant differences in measured resilience indicators in the ANOVA model. The mean change between rounds was not different between each factor, whereas communities with completed C4C projects showed statistically significant growth in three of the four resilience factors (see Table 2 and Figure 5). The results for this model suggest that where communities completed their projects there was a significant increase in social resilience indicators when compared to economic indicators. It is important to note that in both rounds, interviewees of communities with completed projects had higher mean social resilience scores than those of communities where projects were not completed. Interviewees of communities with completed projects started with higher levels of social resilience indicators and, in 
Markantoni, M., Steiner, A., Meador, E. and Farmer, J. (2018) Do community empowerment and enabling state policies work in practice? Insights from a community development intervention in rural Scotland. Geoforum, 97, 142-154.

addition, raised their social resilience indicators at a higher rate than their economic resilience indicators, compared with interviewees of those communities where projects were incomplete.

The effect size of the completed community project model parameters that were statistically significant were between about 1.00 to 1.38 , indicating that in communities that completed their projects, there was an increased level of social resilience indicators among interviewees, about $10-14 \%$ over the course of the programme, as compared to economic resilience indicators. Conversely, interviewees of communities with uncompleted projects did not have a statistically significant increase in either of social and economic resilience indicators between rounds.

\subsection{Social Resilience}

The results suggest that interviewees from communities with completed $\mathrm{C} 4 \mathrm{C}$ projects scored high for both SCR and SIR indicators. Based on the results of Figure 4, SCR increased at a higher percentage than ECR. The same is true for SIR and EIR, suggesting that increased social resilience factors, as compared to economic factors, are important characteristics of successful community development efforts.

Different aspects of community participation (Table 3) observed in both types of community can help to explain why social resilience scores were high, as shown in Figures 3 and 4 . Study participants were asked during the interviews to elaborate on their social resilience scores and provide examples of how they engaged with other community members. In particular, we asked the study participants to give examples of how community members were encouraged to be involved in community life (Q28). According to the respondents, the communities with uncompleted projects relied on more informal means of community engagement (e.g. local pub, café, and church), whereas communities which finalised their $\mathrm{C} 4 \mathrm{C}$ projects had more formal, organised 
Markantoni, M., Steiner, A., Meador, E. and Farmer, J. (2018) Do community empowerment and enabling state policies work in practice? Insights from a community development intervention in rural Scotland. Geoforum, 97, 142-154.

activities, perhaps demonstrating more commitment towards supporting community activities (e.g. community council, community development trusts, and welfare committee).

However, despite the differences in the types of engagement, in both types of the C4C communities, respondents mentioned that they worked together in times of crisis when there was a threat to a community (e.g. development of a landfill site in a close geographical proximity), or a threat of losing a community service (e.g. a school or a church). For example, in one community (C1), local residents worked together and organised a petition to protect a local church from being closed. Although their efforts did not ultimately save the church, this particular situation created an opportunity for people to come together: 'If we have an issue, we act together for everybody's interest' (C1-18). Interviewees from other communities echoed this statement, showing that community spirit and support exist widely among community members in all of the communities: 'If there is something major, the village will pull together and help' (U525). 
Markantoni, M., Steiner, A., Meador, E. and Farmer, J. (2018) Do community empowerment and enabling state policies work in practice? Insights from a community development intervention in rural Scotland. Geoforum, 97, 142-154.

Table 3. Experiences of engaging in community life (these results are derived from the interviews with participants in round 2)

\begin{tabular}{|c|c|}
\hline Completed projects & Uncompleted projects \\
\hline 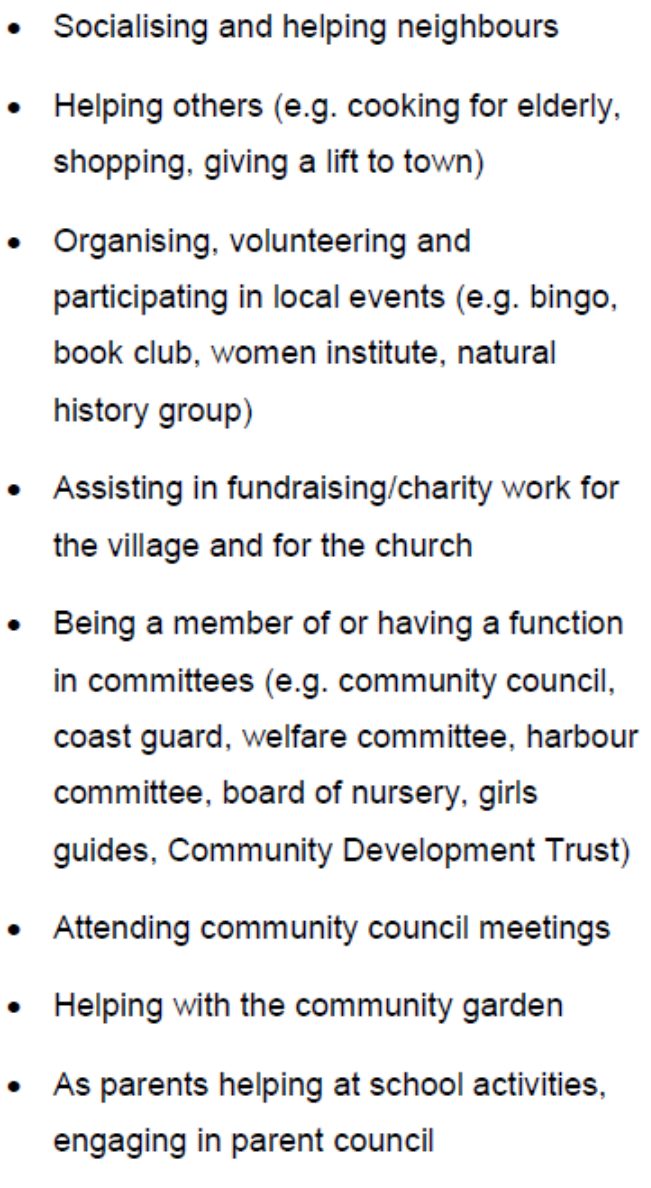 & $\begin{array}{l}\text { - Socialising, visiting neighbours and friends, } \\
\text { walking the dogs } \\
\text { - Helping others in the village (e.g. shopping, } \\
\text { giving a lift to town, keeping an eye on } \\
\text { neighbours' houses) } \\
\text { - Organising, volunteering and participating } \\
\text { in local events (e.g. over } 50 \text { s club, book } \\
\text { club, bingo night, craft group, youth project, } \\
\text { pigeon shooting, Gala event, Ceilidh, } \\
\text { garden party) } \\
\text { - Contributing to the community newsletter } \\
\text { - Visiting the church } \\
\text { - Meeting people in local pub and café } \\
\text { - Having a business/shop in the village } \\
\text { - As parents, having connections with other } \\
\text { parents, casually meeting them school gate } \\
\text { and participating at school meetings } \\
\text { Participating in community gardening }\end{array}$ \\
\hline
\end{tabular}

\subsection{Economic Resilience}

The results presented in Figure 4 show that communities where $\mathrm{C} 4 \mathrm{C}$ projects were completed tended to show an increase in economic resilience indicators over time, whereas communities with incomplete projects had a slight, non-significant, decrease. However, respondents from communities with completed projects reported higher levels of social resilience than economic resilience. In order to explore this issue, study participants were asked to give examples on how community groups worked together to generate income for their village (Q24) (Table ). Interviewees observed that separate groups in the community tended to organise and host fundraising activities for specific 
Markantoni, M., Steiner, A., Meador, E. and Farmer, J. (2018) Do community empowerment and enabling state policies work in practice? Insights from a community development intervention in rural Scotland. Geoforum, 97, 142-154.

organisations (e.g. Parkinson's Association) or particular subgroups within a community (e.g. school, youth club, and church). Respondents from communities with unsuccessful C4C projects highlighted a limited interaction between (sub)groups that reduced the chances of generating revenue for the community, with several stating that their community was fragmented.

Table 4. How community groups work together to generate income for the village (these results are derived from the interviews with participants in round 2)

\begin{tabular}{|c|c|}
\hline Completed projects & Uncompleted projects \\
\hline $\begin{array}{l}\text { - Fundraising activities organised by } \\
\text { community councils, various community } \\
\text { raffles with prizes, concerts in the } \\
\text { village hall, coffee mornings, gala event } \\
\text { - Developing new funding applications for } \\
\text { improvements in the village such as the } \\
\text { local harbour (e.g. Big Lottery, EU) } \\
\text { - Local businesses supporting (e.g. } \\
\text { financially) community initiatives } \\
\text { - Local businesses work together to } \\
\text { increase the number of tourists and } \\
\text { create more local jobs }\end{array}$ & $\begin{array}{l}\text { - Fundraising activities organised by } \\
\text { community councils, various community } \\
\text { committees, schools and also by individuals } \\
\text { (e.g. gala week, coffee mornings, lunch } \\
\text { bunch, buffet night, bring and buy, art and } \\
\text { craft open studios event, community fairs, } \\
\text { bowling green events) } \\
\text { - Generating income though hire charges for } \\
\text { using the village hall } \\
\text { - Community Benefit money from a nearby } \\
\text { wind farm } \\
\text { Community garden as an example where } \\
\text { people worked hard to raise money for the } \\
\text { garden but did not support running and } \\
\text { maintaining it }\end{array}$ \\
\hline
\end{tabular}

${ }^{*}$ This question is an elaboration of Question 24 from the C4C survey.

Across all the communities, interview data revealed one contentious point. This related to the uneven level of participation in activities for generating income for the community, with very few community members volunteering time and skills on a regular basis to support fundraising activities. Respondents also suggested that there was a lack of willingness among a wide range of local people to help in community affairs: 
Markantoni, M., Steiner, A., Meador, E. and Farmer, J. (2018) Do community empowerment and enabling state policies work in practice? Insights from a community development intervention in rural Scotland. Geoforum, 97, 142-154.

'They're the same people doing all things, and they can't do it all. People are ready to take but not to give' (U4-42). Statements like these were supported by other interviewees: 'You see the same faces doing things' (U4-13). This raises important questions about community and individual capacity, time and energy commitment for running and managing community projects, as well as questions about established groups which, intentionally or unintentionally and for various reasons, are not open to all community members. For instance, in one of the communities there was a division between younger and older people, who had different community development visions. In another community, there was an observable division between people born locally and incomers. These issues were indicated as important in influencing the economic viability of local communities.

\section{Discussion}

C4C was tailored to support the development of local skills (e.g. project management and implementation of local improvements) and to build the capacity of local residents at the community level, in communities defined by policy as 'hard-to-reach', with the intention of enhancing community resilience. We found that $\mathrm{C} 4 \mathrm{C}$ projects were completed in half of the rural communities where they were begun. Since these were communities that had not previously engaged in community projects (by our definition), this could be considered a positive outcome. However, we would like to point out certain caveats.

First, although helpful, public grants and support from community development programmes such as LEADER cannot guarantee the successful outcome of community projects. This is especially the case for hard-to-reach communities, which are less likely to engage in activities requiring civic participation. 
Markantoni, M., Steiner, A., Meador, E. and Farmer, J. (2018) Do community empowerment and enabling state policies work in practice? Insights from a community development intervention in rural Scotland. Geoforum, 97, 142-154.

Second, as evidenced by our results, interviewees from communities that completed C4C projects rated highly for both SCR and SIR across all indicators. Over the timespan studied, SCR increased by a greater amount than ECR, which indicates that social resilience factors are more important predictors of successful community development efforts than economic resilience factors. Communities with incomplete projects did not have a statistically significant increase or decrease in either of social or economic resilience indicators between rounds, which could indicate that targeted (external) support (not only financial support but also support for strengthening social capital) could be beneficial for those type of communities. However, respondents from both types of communities suggested that social bonds between the residents were strong. The communities that exhibited the effects of strong social ties had experienced critical times when community members worked together to keep local facilities open. Social resilience was thus proved to matter especially in times of crisis, and it helped communities to come out of the process stronger and more resilient.

Our findings suggest that social resilience is important for completing community projects, but that it is also important for a community to have a level of social resilience prior to starting such projects. In relation to strengthening community resilience, our study indicated that, although social resilience is a predictor of successful implementation of community projects, it is even more important to understand that the different dimensions of community resilience (economic and social resilience at the individual and community levels) are interlinked. Resilience is not based on a single factor, nor is it related to economic or social issues separately. Rather, our analysis suggested that perceptions of the local economy, social interactions and community are inter-related, and resilience is dependent on all simultaneously.

Although relevant to policy, research and practice, the findings presented here have some limitations. Our study was conducted in a specific type of community, i.e. small, rural, largely populated by older citizens and with no previous engagement in LEADER 
Markantoni, M., Steiner, A., Meador, E. and Farmer, J. (2018) Do community empowerment and enabling state policies work in practice? Insights from a community development intervention in rural Scotland. Geoforum, 97, 142-154.

or other major funding initiatives. It raises, therefore, a number of questions that we did not explore in this research. For example, do communities with younger people have a better chance of developing their capacity and enhancing community resilience? Also, communities that succeeded in finalising their projects had higher resilience levels to start with. With this in mind, how and from what activities or resources was resilience built? It also raises the question of why these communities had not previously applied for community development grants. Future studies could expand on the presented evidence by conducting research in communities with different characteristics. Also, our quantitative findings are based on a specific Analytical Resilience Framework (Steiner and Markantoni, 2014), and could vary if other community resilience measurement tools were applied (especially given the non-concrete nature of our current understanding and definition of 'community resilience'). Without more quantitative studies in the field, it is difficult to compare our findings with other research results and comment on what represents, for example, a good or very good increase in the level of resilience.

\section{Conclusion}

Our research adds to the current knowledge base by enhancing our understanding of the effect of community interventions on community resilience - here measured as a change in social and economic indicators at individual and community levels. The $\mathrm{C} 4 \mathrm{C}$ initiative illustrated that social resilience factors such as strong social ties, networks, and community confidence and pride were associated with completed community projects. Communities that lacked social ties were more likely to require external support from the state to develop skills and capacity. However, support should not only be financial but should also help realise local capacities and the creative potential of local people so that they can play a more active role in addressing local challenges. 
Markantoni, M., Steiner, A., Meador, E. and Farmer, J. (2018) Do community empowerment and enabling state policies work in practice? Insights from a community development intervention in rural Scotland. Geoforum, 97, 142-154.

The active involvement of community members can, in turn, lead to more resilient and stronger communities. While we observed that resilience increased in communities that completed their projects, we are unable to state precisely what causal combination of factors and processes led to this increase. Consequently, we are unable to comment on why and how $\mathrm{C} 4 \mathrm{C}$ provided the extra stimulation for these communities - which already had higher resilience than non-completers - to actually participate and complete. We recognise that in all of the communities only a small proportion of the community got involved; the extent of this critical mass is significant. The dynamics in communities that completed their $\mathrm{C} 4 \mathrm{C}$ projects suggests that there may be a 'tipping point' at which latent capacity can be enabled by some additional resource or stimulus. Perhaps this is what occurred with C4C. It may be that layers and iterations of capacity building over time can help to build, incrementally, the trust, community confidence and sense of identity that underpin successful collective efforts.

This leads us to suggest that, in order to strengthen community resilience in the shift to an enabling state, governments should assist communities by creating conditions in which people within communities (those that are hard to reach and others) are able to take action to improve their own wellbeing. One might envision a more active role for the state with enabling activities as a pre-requisite and then, once some capacity is built, with the state acting more as a collaborator and a partner to help communities find and apply appropriate solutions (Coaffee et al. 2008). In line with Elvidge (2014), such an enabling state would provide the right sort of 'helping' hand at different stages of community development, which might mean different things in different places and for different stages in the development of civic participation. Communities that have the support of the state (in financial and non-financial terms) should grow in skills and confidence, be in a better position to respond to future challenges and be more strategic about the future. Changes in resilience levels and the effects of interventions 
Markantoni, M., Steiner, A., Meador, E. and Farmer, J. (2018) Do community empowerment and enabling state policies work in practice? Insights from a community development intervention in rural Scotland. Geoforum, 97, 142-154.

should become evident over time, but such measurements were beyond the scope of this study, which spanned only two-years.

State responsibilities are in transition from service delivery to requesting communities to co-produce services. Such a transition will require governmentcommunity relations that build readiness, provide guidance and support, and stimulate community animation. With a rapidly changing socio-economic environment and emerging policies on community resilience, a better understanding of levels and types of state support locally, with regard to different community capacities, is required. Dependence on the state will still exist but it will take a different form. This implies that more evidence is needed to determine what appropriate levels of local support from the state should look like. That would also imply an active role from both the state and communities in the form of local community consultations and conversations for shaping not only more targeted local action plans but national policies, community programmes and budgets as well (e.g. participatory budgeting). In time, it is likely that we will observe a drift away from a dependency culture to a new normative state where community members drive local development forward. Public spending cuts, withdrawal of services and a socio-economic transition create push factors that impose a new way of thinking in which adaptation is required to survive. At this stage, however, our research showed that the process of moving towards independent, empowered and resilient communities will require moving towards targeted support for those communities that need it the most, in order to ensure that all communities have the capacity to act.

\section{Acknowledgements}

This research was undertaken within the Scottish Government Rural Affairs and Environment Portfolio Strategic Research Programme (RESAS) 2011-16, Work Package 8.2 ‘Governance and 
Markantoni, M., Steiner, A., Meador, E. and Farmer, J. (2018) Do community empowerment and enabling state policies work in practice? Insights from a community development intervention in rural Scotland. Geoforum, 97, 142-154.

Decision-Making for Community Empowerment'. The paper also links with the Research

Deliverable 3.4.4 on Local Assets, Local Decisions and Community Resilience funded under the

RESAS Programme 2016-2021. The authors would like to thank all the respondents for their valuable time and the sharing of information, which made this research possible. Many thanks also to Prof Frank Vanclay for his comments and edits on an earlier version of this paper. Finally we would like to also thank the anonymous reviewers for their comments and suggestions that helped to further revise our paper. We are grateful.

\section{References}

Adger, W.N. 2000. Social and ecological resilience: Are they related? Progress in Human Geography 24 (3), 347-364.

Adger, W.N. 2006. Vulnerability. Global Environmental Change 16 (3), 268-281.

Bock, B. 2016. Rural marginalisation and the role of social innovation: A turn towards nexogenous development and rural reconnection. Sociologia Ruralis 56 (4), 552573.

Brodie, E. 2015.Local Democracy in Rural Scotland. Rural Policy Centre Policy Briefing. January 2015 (RPC PB 2015/03). Accessed online 7 January 2018 at: https://www.sruc.ac.uk/download/downloads/id/2315/2015_local_democracy_in_rural _scotland

Brown, A. 2001. The Scottish Parliament: hopes and aspirations. Scottish Affairs 37 (2), 78-84.

Cable, V. 1994. The World's New Fissures: Identities in Crisis. London: Demos. Accessed online 10 February 2018 at: https://www.demos.co.uk/files/theworldsnewfissures.pdf

Carnegie UK Trust 2013. The Enabling State in Scotland. Dunfermline: Carnegie UK Trust.

Cheshire, L., Esparcia, J., Shucksmith, M. 2015. Community resilience, social capital and territorial governance. AGER Journal of Depopulation and Rural Development Studies 18 (1), 7-38.

Christie, C. 2011. Commission on the future delivery of public services. Edinburgh: APS Group Scotland.

Conservative Party 2015. Strong Leadership, a clear economic plan, a brighter more secure future. The Conservative Party Manifesto. Accessed online 7 December 
Markantoni, M., Steiner, A., Meador, E. and Farmer, J. (2018) Do community empowerment and enabling state policies work in practice? Insights from a community development intervention in rural Scotland. Geoforum, 97, 142-154.

2017 at: https://s3-eu-west-

1.amazonaws.com/manifesto2015/ConservativeManifesto2015.pdf

Cope, S., Leishman, F., Starie, P. 1997. Globalisation, new public management and the enabling state: Futures of police management. International Journal of Public Sector Management 10 (6), 444-460.

Dare, M., Schirmer, J., Vanclay, F. 2014. Community engagement and social licence to operate. Impact Assessment \& Project Appraisal 32 (3), 188-197.

Darnhofer, I., Lamine, C., Strauss, A., Navarrete, M. 2016. The resilience of family farms: Towards a relational approach. Journal of Rural Studies 44, 111-122.

Davoudi, S. 2012. Resilience: A bridging concept or a dead end? Planning Theory \& Practice 13 (2), 299-307.

Dawley, S., Pike, A., Tomaney, J. 2010. Towards the resilient region? Local Economy 25 (8), 650-667.

Dax, T., Strahl, W., Kirwan, J. and Maye, D. 2016. The Leader programme 2007-2013: Enabling or disabling social innovation and neo-endogenous development? Insights from Austria and Ireland. European Urban and Regional Studies 23 (1), 56-68.

Elliot, A. 2014. Principles of Community Engagement. In: Royal Society of Edinburgh. Advice Paper on Community Empowerment and Capacity Building, Appendix B. pp.26-28. Accessed online 28 January 2018 at: https://www.rse.org.uk/wpcontent/uploads/2016/09/AP14_08.pdf

Elvidge, J. 2012. The Enabling State: Discussion Paper. Dunfermline: Carnegie UK Trust. Accessed online 28 January 2018 at: http://www.carnegieuktrust.org.uk/carnegieuktrust/wpcontent/uploads/sites/64/2016/02/pub14550116191.pdf

Elvidge, J. 2014. A Route Map to an Enabling State. Dunfermline: Carnegie UK Trust.

Farmer, J., Steinerowski, A., Jack, S. 2008. Starting social enterprises in remote and rural Scotland: best or worst of circumstances? International Journal of Entrepreneurship and Small Business 6 (3), 450-464.

Gilbert, N. 2005. The 'Enabling State?' from Public to Private Responsibility for Social Protection: Pathways and Pitfalls. OECD Social, Employment and Migration Working Papers, No. 26, Paris: Organisation for Economic Co-operation and Development.

Granberg, K. Andersson, Kovách, I. 2015. Evaluating the European Approach to Rural Development, Grass-roots Experiences of the LEADER Programme. Perspectives on Rural Policy and Planning. Farnham: Ashgate.

Harrow, J., Jung, T. 2016. Philanthropy and community development: the vital signs of community foundation? Community Development Journal 51 (1), 132-152. 
Markantoni, M., Steiner, A., Meador, E. and Farmer, J. (2018) Do community empowerment and enabling state policies work in practice? Insights from a community development intervention in rural Scotland. Geoforum, 97, 142-154.

Herman, A. 2016. 'More-than-human' resilience(s)? Enhancing community in Finnish forest farms. Geoforum 69, 34-43.

Imperiale, A.J., Vanclay, F. 2016. Experiencing local community resilience in action: Learning from post-disaster communities. Journal of Rural Studies 47, 204-219.

Johansen, P.H., Chandler, T.L. 2015. Mechanisms of power in participatory rural planning. Journal of Rural Studies 40 (7), 12-20.

Kelly, C., Ferrara, A., Geoff, A. Wilson, Ripullone, F., Nolè, A., Harmer, N., Salvati, L. 2015. Community resilience and land degradation in forest and shrubland socioecological systems: Evidence from Gorgoglione, Basilicata, Italy. Land Use Policy 46, 11-20,

Kleinbaum, D., Kupper, L., Nizam, A. and Rosenberg, E. 2013. Applied regression analysis and other multivariable methods. Boston: Nelson Education.

Lewicka, M. 2011. Place attachment: how far have we come in the last 40 years? Journal of Environmental Psychology, 31 (3), 207-230.

Magis, K., 2010. Community resilience: an indicator of social sustainability. Society and Natural Resources 33 (5), 401-416.

McEvoy, D., Fünfgeld, H., Bosomworth, K. 2013. Resilience and climate change adaptation: The importance of framing. Planning Practice \& Research 28 (3), 280-293.

McManus, P., Walmsley, J., Argent, N., Baum, S., Bourke, L., Martin, J., Pritchard, B., Sorensen, T. 2012. Rural community and rural resilience: What is important to farmers in keeping their country towns alive? Journal of Rural Studies 28 (1), 2029.

Meador, J., Skerratt, S. 2017. On a unified theory of development: New institutional economics and the charismatic leader. Journal of Rural Studies 53, 144-155.

Mitchell, A. 2013. Risk and Resilience: From Good Idea to Good Practice. OECD Development Co-operation Working Papers No.13, Paris: Organisation for Economic Co-operation and Development. http://dx.doi.org/10.1787/5k3ttg4cxcbpen

Mohan, G., Stokke, K. 2000. Participatory development and empowerment: the dangers of localism. Third World Quarterly 21 (2), 247-268.

Muñoz, S-A., Steiner, A., Farmer, J. 2015. Processes of community-led social enterprise development: Learning from the rural context. Community Development Journal 50 (3), 478-493.

Navarro, F. A., Woods, M., Cejudo, E. 2015. The LEADER Initiative has been a victim of its own success: The decline of the bottom-up approach in rural development programmes. The cases of Wales and Andalusia. Sociologia Ruralis 56 (2), 270288. 
Markantoni, M., Steiner, A., Meador, E. and Farmer, J. (2018) Do community empowerment and enabling state policies work in practice? Insights from a community development intervention in rural Scotland. Geoforum, 97, 142-154.

Prime Minister's Office 2017. The government's negotiating objectives for exiting the EU: PM speech. Prime Minister Theresa May set out the Plan for Britain, including the 12 priorities that the UK government will use to negotiate Brexit. Accessed online 28 January 2018 at: https://www.gov.uk/government/speeches/the-governments-negotiating-objectives-forexiting-the-eu-pm-speech

Rigg, J., Salamanca, A., Parnwell, M. 2012. Joining the dots of agrarian change in Asia: a 25 Year view from Thailand. World Development 40 (7), 1469-1481.

Schwarz, A., Béné, C., Bennett, G., Boso, D., Hilly, Z., Paul, C., Posala, R., Sibiti, S., Andrew, N. 2011. Vulnerability and resilience of remote rural communities to shocks and global changes: Empirical analysis from Solomon Islands. Global Environmental Change 21 (3), 128-1140.

Scott, M. 2013. Resilience: A conceptual lens for rural studies? Geography Compass 7 (9), 597-610.

Scottish Government 2015a. A Stronger Scotland. The Government's Programme for Scotland 2015-2016. Edinburgh: The Scottish Government.

http://www.gov.scot/Resource/0048/00484439.pdf

Scottish Government 2015b. Analytical paper on co-production. Working Paper - Office of the Chief Social Policy Advisor. Edinburgh: The Scottish Government. Accessed online 28 January 2018 at: http://www.gov.scot/Resource/0047/00477490.pdf

Scottish Government 2015c. Community Empowerment (Scotland) Act 2015. Accessed online 28 January 2018 at:

http://www.legislation.gov.uk/asp/2015/6/contents/enacted

Scottish Government 2017. The Scottish Index of Multiple Deprivation Accessed online 28 January 2018 at: http://www.gov.scot/Topics/Statistics/SIMD

Shortall, S. 2008. Are rural development programmes socially inclusive? Social inclusion, civic engagement, participation, and social capital: Exploring the differences. Journal of Rural Studies 24 (4), 450-457.

Shucksmith, M. 2000. Endogenous development, social capital and social inclusion: Perspectives from LEADER in the UK. Sociologia Ruralis 40 (2), 208-218.

Shucksmith, M. 2012. Future Directions in Rural Development? Dunfermline: Carnegie UK Trust.

Skerratt, S., Steiner, A. 2013. Working with communities-of-place: Complexities of Empowerment. Local Economy 28 (3), 320-338.

Skerratt, S., Atterton, J., McCracken, D., McMorran, R., Thompson, S. 2016. Rural Scotland in Focus. Edinburgh: Scotland's Rural College. Accessed online 16 February 2018 at: https://www.sruc.ac.uk/info/120428/rural_scotland_in_focus 
Markantoni, M., Steiner, A., Meador, E. and Farmer, J. (2018) Do community empowerment and enabling state policies work in practice? Insights from a community development intervention in rural Scotland. Geoforum, 97, 142-154.

Smyth, E., Vanclay, F. 2017. The Social Framework for Projects: A conceptual but practical model to assist in assessing, planning and managing the social impacts of projects. Impact Assessment \& Project Appraisal 35 (1), 65-80.

Steiner, A. 2016. Assessing the effectiveness of a capacity building intervention in empowering hard to reach communities. Journal of Community Practice 24, 235263.

Steiner, A., Atterton, J. 2015. Exploring the contribution of rural enterprises to local resilience. Journal of Rural Studies, 40, 30-45.

Steiner, A. A., Farmer, J. 2017. Engage, participate, empower: Modelling power transfer in disadvantaged rural communities. Environment and Planning C: Politics and Space 36 (1), 118-138. https://doi.org/10.1177\%2F2399654417701730

Steiner, A., Markantoni, M. 2014. Exploring community resilience in Scotland through Capacity for Change. Community Development Journal 49 (3), 407-425.

Steiner, A., Woolvin, M., Skerratt, S. 2016. Measuring community resilience: developing and applying a 'hybrid evaluation' approach. Community Development Journal 53 (1), 99-118 https://doi.org/10.1093/cdj/bsw017

The Commission on Strengthening Local Democracy, 2014. Effective Democracy: Reconnecting with Communities. Accessed online 16 February 2018 at: http://www.localdemocracy.info/wp-content/uploads/2014/08/Final-Report-August2014.pdf

Tohidi, H., Jabbari, M.M. 2012. The aspects of empowerment of human resources. Procedia-Social and Behavioural Sciences 31, 829-833.

Vanclay, F. 2015. The potential application of qualitative evaluation methods in European regional development: Reflections on the use of Performance Story Reporting in Australian natural resource management. Regional Studies 49 (8), 1326-1339.

Vanclay, F., Baines, J. \& Taylor, C.N. 2013. Principles for ethical research involving humans: Ethical professional practice in impact assessment Part I. Impact Assessment \& Project Appraisal 31 (4), 243-253.

Vanclay, F., Esteves, A.M., Aucamp, I., Franks, D. 2015. Social Impact Assessment: Guidance for assessing and managing the social impacts of projects. Fargo ND: International Association for Impact Assessment.

Westwood, A. 2011. Localism, social capital and the 'Big Society'. Local Economy 26 (8), 690-701.

Wilkinson, K. 1991. The Community in Rural America. New York: Greenwood Press.

Wilson, G. 2012a. Community resilience, globalisation, and transitional pathways of decision making. Geoforum 43 (6), 1218-1231.

Wilson, G. A. 2012b. Community Resilience and Environmental Transitions. London: Routledge. 
Markantoni, M., Steiner, A., Meador, E. and Farmer, J. (2018) Do community empowerment and enabling state policies work in practice? Insights from a community development intervention in rural Scotland. Geoforum, 97, 142-154.

Wilson, G.A. 2013. Community resilience, policy corridors and the policy challenge. Land Use Policy 31, 298-310.

Wilson, G.A. 2014. Community resilience: path dependency, lock-in effects and transitional ruptures. Journal of Environmental Planning and Management 57 (1), $1-26$.

Wilson, G.A., Quaranta, G., Kelly, C., Salvia, R. 2016. Community resilience, land degradation and endogenous lock-in effects: evidence from the Alento region, Campania, Italy. Journal of Environmental Planning and Management 59 (3), 518-537.

Wilson, G.A., Hu, Z. , Rahman, S. 2018. Community resilience in rural China: The case of Hu Village, Sichuan Province. Journal of Rural Studies 60, 130-140,

Woods, D.M. 2016. Community indicators and collective impact: facilitating change. Community Development 42 (2), 194-208.

Wright, K. 2016. Resilient communities? Experiences of risk and resilience in a time of austerity. International Journal of Disaster Risk Reduction 18 (1), 154-161.

Zwiers, S., Markantoni, M., Strijker, D. 2018. The role of change- and stability-oriented place attachment in rural community resilience: a case study in south-west Scotland. Community Development Journal 53 (2), 281-300. https://doi.org/10.1093/cdj/bsw020 
Markantoni, M., Steiner, A., Meador, E. and Farmer, J. (2018) Do community empowerment and enabling state policies work in practice? Insights from a community development intervention in rural Scotland. Geoforum, 97, 142-154.

\section{Appendix 1.}

Figure 6 . Kernel density of change between rounds

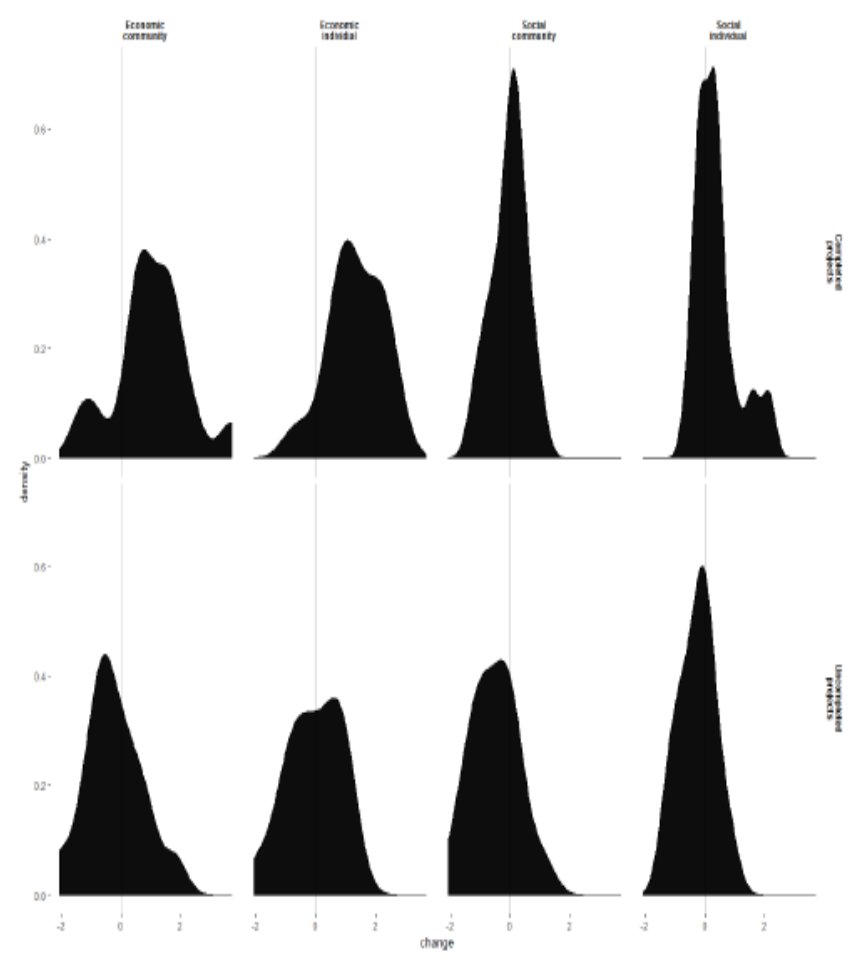

